\title{
EFFECTS OF LOW AND SEVERE UNDERWEIGHT ON THE RISK OF CHILD DYING FROM HIV/AIDS: A META-ANALYSIS
}

\author{
Dyah Ambarwati'), Yulia Lanti Retno Dewi'), Bhisma Murti') \\ 1)Masters Program in Public Health, Universitas Sebelas Maret \\ 2)Faculty of Medicine, Universitas Sebelas Maret
}

\begin{abstract}
Background: Malnutrition in the background of HIV/AIDS is a complex medical condition contributing to premature death and the development of comorbidities for affected children. A systematic review and meta-analysis was conducted to examine the effects of low and severe underweight on the risk of child dying from HIV/AIDS: a meta-analysis.

Subjects and Method: A meta analysis study was conducted by collecting articles from Google scholar and PubMed databases. The article search method is carried out using several methods, including boolean operators, handsearching, keywords, and MesH. The inclusion criteria were cohort study. The articles were systematically collected by PRISMA-P flow chart. Selected articles were analyzed using Review Manager 5.3 application software.

Results: Low body weight $(\mathrm{aHR}=2.14 ; 95 \% \mathrm{CI}=1.92$ to $2.39 ; \mathrm{p}<0.001)$ and severe low body weight $(\mathrm{aHR}=2.86 ; 95 \% \mathrm{CI}=1.76$ to $4.64 ; \mathrm{p}<0.001)$ increased the risk of child death infected by HIV/AIDS.

Conclusion: Low body weight and severe low body weight increase the risk of child death infected by HIV/AIDS.
\end{abstract}

Keywords: low body weight, severe low body weight, child death, HIV/AIDS

\section{Correspondence:}

Dyah Ambarwati. Masters Program in Public Health, Universitas Sebelas Maret, Jl. Ir. Sutami 36A, Surakarta 57126, Central Java. Email: ambarwati.dyah27@gmail.com. Mobile: +6287735486570 . 